\title{
Pengaruh Social Learning Network Berbasis Edmodo Terhadap Pemahaman Konsep dan Prestasi Belajar
}

\author{
Charla Nadira Caidhani ${ }^{1}$, Vertika Panggayuh ${ }^{2}$ \\ ${ }^{1,2}$ Pendidikan Teknologi Informasi \\ ${ }^{1}$ caidhani34@gmail.com \\ 2vertika.a6@gmail.com \\ ${ }^{2}$ STKIP PGRIOTulungagung \\ ${ }^{2}$ stkippgritulungagung.ac.id
}

\begin{abstract}
Abstrak - Pada era digital saat ini, perkembangan teknologi tumbuh dengan pesat dan menciptakan sebuah fenomena interaksi secara virtual atau tidak langsung (online). Penggunaan teknologi secara optimal sebagai upaya untuk memudahkan interaksi dengan siswa dalam proses belajar diharapkan telah terintegrasi dengan Social Learning Network (SLN). Salah satu media $S L N$ yang dapat menunjang kelas digital yaitu $E d m o d o$. Edmodo adalah media pembelajaran jejaring sosial dan platform micro blogging yang aman dimana guru dan siswa dapat berinteraksi dan berkolaborasi secara online. Penelitian ini bertujuan untuk menguji pengaruh $S L N$ Edmodo terhadap pemahaman konsep siswa dan pengaruh $S L N$ Edmodo terhadap prestasi belajar siswa pada mata pelajaran Simulasi Digital di SMKN 2 Trenggalek. Penelitian ini menggunakan metode Pretest-Posttest Control Group Design dengan bentuk Nonequivalent Control Group Design. Pada desain ini peneliti menggunakan pola Pretest-Posttest Control Group Design. Populasi adalah seluruh siswa kelas $X$ jurusan Rekayasa Perangkat Lunak di SMK Negeri 2 Trenggalek tahun pelajaran 2017/2018 berjumlah 107 siswa. Sampel 72 siswa yang terbagi dalam dua kelas yang diambil dengan teknik Sampling Purposive. Teknik analisis data menggunakan uji normalitas, uji linieritas, uji homogenitas, uji daya pembeda, uji tingkat kesukaran dan uji t-test dengan bantuan SPSS versi 23. Pengumpulan data dilakukan berupa angket, tes dan dokumentasi nilai. Hasil pengujian hipotesis dengan analisis uji t-test menunjukkan bahwa nilai signifikansi pemahaman konsep $\left(Y_{1}\right)$ sebesar $\alpha=0,796>0,05$ dan signifikansi prestasi belajar $\left(Y_{2}\right)$ sebesar $\alpha=0,563>0,05$. Dengan demikian maka hipotesis nol diterima, kesimpulannya yaitu media SLN Edmodo berpengaruh terhadap pemahaman konsep dan prestasi belajar siswa di SMK Negeri 2 Trenggalek.
\end{abstract}

Kata Kunci- Angket, Eksperimen, Kontrol, SLN Edmodo, Tes.

\section{Pendahuluan}

Kegiatan pembelajaran yang dilakukan pada Sekolah Menengah Kejuruan (SMK) pada umumnya lebih mengarah kepada pengembangan kompetensi dan keterampilan. Sesuai dengan tujuan SMK adalah sebagai salah satu institusi yang menyiapkan tenaga kerja, dituntut mampu menghasilkan lulusan sebagaimana yang diharapkan oleh dunia kerja. Praktik kerja industri (prakerin) adalah suatu cara menyelenggarakan pendidikan dan pelatihan kejuruan khususnya pada SMK Negeri 2 Trenggalek yang memadukan kegiatan belajar di sekolah dan kegiatan belajar melalui bekerja langsung pada bidang serta suasana yang sesungguhnya dan relevan di lapangan kerja/dunia usaha dan atau dunia industri dengan harapan terjadi keterkaitan dan kesepadanan antara sekolah dengan dunia industri. Mengingat keterbatasan dari pihak industri dalam menerima siswa prakerin, maka pelaksanaannya dilakukan secara bertahap dalam bentuk kelompok-kelompok kecil dan tersebar di beberapa industri yang ada di wilayah Trenggalek maupun di luar wilayah Trenggalek.

Dengan demikian proses pembelajaran yang dilakukan oleh siswa akan sulit untuk dilakukan pada tatap muka di kelas saat siswa melakukan prakerin. Kondisi objektif yang dapat peneliti amati bahwa di SMK Negeri 2 Trenggalek agar siswa tidak tertinggal dalam memperoleh materi pelajaran selama proses prakerin maka diperlukan sebuah kelas digital yang dapat menjadi perantara siswa dengan guru untuk memberikan materi, kuis, diskusi maupun tugas. Dalam mempersiapkan prakerin tersebut siswa diberi pelatihan agar dapat memanfaatkan teknologi ke dalam sebuah kelas digital

Selain itu, penerapan kelas digital juga dapat dijadikan sebagai nilai tambah untuk mengatasi kendala yang terjadi pada kelas tradisional, yang tediri dari 1) rendahnya motivasi siswa di dalam belajar, seperti malas membaca buku; 2) siswa memiliki kecenderungan menghilangkan modul dalam bentuk cetak, ketinggalan, rusak dan lain-lain; 3) siswa cenderung lemah dalam memahami teori. Untuk mengatasi hal ini, yang dilakukan dalam pemanfaatan teknologi informasi dan komunikasi adalah mentrasformasikan modul pembelajaran dalam bentuk cetak menjadi non cetak (online).

Peneliti menggunakan Social Learning Network (SLN) yang merupakan adaptasi dari Learning Management System (LMS) namun berbasiskan sosial media (media social) dan dapat diimplementasikan ke Sekolah Menengah Kejuruan menuju sekolah berbasis teknologi informasi dan komunikasi (TIK). Social Learning Network (SLN) atau jejaring sosial untuk pembelajaran, menurut Kordesh (2000) seperti dikutip Direktorat Pembinaan SMK (2017) merujuk pada koneksi interpersonal melalui interaksi dengan tujuan utama untuk pengembangan pengetahuan[1].

Edmodo adalah sebuah media untuk melaksanakan pembelajaran secara daring. Edmodo menggabungkan sebagian fitur dari Learning Management System (LMS) dan sebagian fitur dari Jejaring Sosial (Social Network), menjadi sebuah media pembelajaran yang menarik dan mudah digunakan, kemudian lebih dikenal dengan Jejaring Sosial Pembelajaran (Social Learning Network)[2].

Penelitian ini untuk mengetahui gambaran: 1) Besarnya pengaruh Social Learning Network Edmodo terhadap pemahaman konsep siswa pada mata pelajaran simulasi digital 
di SMKN 2 Trenggalek, dan 2) Besarnya pengaruh Social Learning Network Edmodo terhadap prestasi belajar siswa pada mata pelajaran simulasi digital di SMKN 2 Trenggalek.

\section{METODE PENELITIAN}

Metode yang digunakan dalam penelitian ini adalah metode penelitian eksperimen dengan pendekatan kuantitatif. Objek penelitiannya adalah siswa kelas $\mathrm{X}$ jurusan Rekayasa Perangkat Lunak di SMK Negeri 2 Trenggalek. Teknik pengumpulan data dengan menggunakan tes, kuesioner (angket) dan dokumentasi nilai. Metode penelitian eksperimen yang digunakan adalah Quasi Experimental Design dengan bentuk Nonequivalent Control Group Design. Pada desain ini peneliti menggunakan pola Pretest-Posttest Control Group Design, yakni pada kelompok eksperimen maupun kelompok kontrol tidak dipilih secara random. Pada desain ini kelompok eksperimen diberi perlakuan menggunakan media pembelajaran Social Learning Network berbasis Edmodo, sedangkan pada kelompok kontrol diberi perlakuan berupa model pembelajaran konvensional. Selanjutnya, kedua kelompok ini dikenai pengukuran yang sama dan dibandingkan hasilnya. Desain pola Pretest-Posttest Control Group Design dijabarkan dalam bentuk tabel sebagai berikut.

TABEL I

RUMUS PENELITIAN PRETEST-POSTTEST CONTROL GROUP DESIGN

[Sumber: Sugiyono, 2016, hal.116]

\begin{tabular}{|c|c|c|c|c|}
\hline Group & $\begin{array}{c}\text { Teknik } \\
\text { Pengambilan }\end{array}$ & Pretest & Treatment & Posttest \\
\hline $\mathrm{E}$ & $\mathrm{R}$ & $\mathrm{O}_{1}$ & $\mathrm{X}$ & $\mathrm{O}_{2}$ \\
$\cdots \mathrm{K}$ & $\mathrm{R}$ & $\mathrm{O}_{3}$ & & $\mathrm{O}_{4}$ \\
\hline
\end{tabular}

Keterangan:

$\mathrm{E} \quad=$ Kelompok eksperimen

$\mathrm{K} \quad=$ Kelompok kontrol

$\mathrm{R} \quad=$ Kelompok eksperimen dan kontrol siswa SMK Negeri 2 Trenggalek diambil secara random

$\mathrm{O}_{1} \& \mathrm{O}_{3} \quad=$ Kedua kelompok tersebut diobservasi dengan pretest untuk mengetahui pemahaman konsep awalnya

$\mathrm{O}_{2} \quad=$ Pemahaman konsep siswa setelah mengikuti pembelajaran Rekayasa Perangkat Lunak dengan SLN Edmodo

$\mathrm{O}_{4} \quad=$ Pemahaman konsep kelompok kontrol setelah mengikuti pembelajaran rekayasa perangkat lunak yang tidak menggunakan SLN Edmodo

$\mathrm{X} \quad=$ Treatment. Kelompok atas sebagai kelompok eksperimen diberi treatment, yaitu pembelajaran menggunakan SLN Edmodo, sedangkan kelompok bawah sebagai kelompok kontrol, pembelajaran tidak menggunakan SLN Edmodo. Pengaruh pembelajaran dengan SLN Edmodo adalah (O2-O4).

\section{A. Variabel Penelitian}

Variabel penelitian ini terdiri dari tiga variabel, yaitu satu variabel bebas (independent variable) dan dua variabel terikat (dependent variable). Variabel bebas adalah Social Learning Network berbasis Edmodo $\left(\mathrm{X}_{1}\right)$, sedangkan variabel terikat adalah pemahaman konsep $\left(\mathrm{Y}_{1}\right)$ dan prestasi belajar siswa $\left(\mathrm{Y}_{2}\right)$. Adapun variabel penelitian disajikan pada tabel sebagai berikut.
TABEL II

INDIKATOR VARIABEL

\begin{tabular}{|c|c|c|c|}
\hline No. & Variabel & Indikator & Instrumen \\
\hline 1. & $\begin{array}{l}\text { SLN } \\
\text { Edmodo } \\
\left(\mathrm{X}_{1}\right)\end{array}$ & $\begin{array}{l}\text { - Dapat memperluas akses jaringan } \\
\text { on campus dan off campus } \\
\text { - Dapat menyiapkan kapasitas } \\
\text { akses internet. } \\
\text { - Dapat menyediakan public access } \\
\text { untuk semua pengajar dan } \\
\text { pembelajar. } \\
\text { - Dapat menyediakan laboratorium } \\
\text { komputer yang online } 24 \text { jam di } \\
\text { lingkungan sekolah dan kampus. } \\
\text { - Berorientasi ke aplikasi open } \\
\text { source. } \\
\text { - Mudah di customize oleh } \\
\text { pengguna. } \\
\text { - Memerlukan pelatihan program } \\
\text { terpadu untuk peningkatan TIK } \\
\text { pembelajar. } \\
\text { - Mampu memaksimalkan sistem } \\
\text { pembelajaran dengan pertemuan } \\
\text { di ruang kelas (tatap muka) } \\
\text { sebanyak 80 \%, dan tidak } \\
\text { terbatas ruang dan waktu melalui } \\
\text { internet sebanyak } 20 \% \text {. } \\
\text { - Mampu mengembangkan materi } \\
\text { dan website e-learning, } \\
\text { melakukan adalah penataan ulang } \\
\text { kurikulum, satuan acara } \\
\text { pembelajaran atau RPP, membuat } \\
\text { outline materi pembelajaran, dan } \\
\text { membuat materi ajar dalam } \\
\text { bentuk multimedia. } \\
\text { - Mampu melakukan } \\
\text { pengembangan dan pengendalian } \\
\text { terhadap infrastuktur e-learning } \\
\text { - Mampu dalam melakukan } \\
\text { administrasi sekolah, pendaftaran } \\
\text { siswa, informasi tentang sekolah } \\
\text { dan penjadwalan. } \\
\text { - Mampu menyampaikan bahan } \\
\text { ajar. Mampu melakukan pengecekan } \\
\text { kompetensi melalui tugas } \\
\text { maupun kuis. } \\
\text { - Mampu melaporkan hasil belajar. } \\
\text { antar siswa maupun siswa dan } \\
\text { pengajar. }\end{array}$ & Angket \\
\hline 2. & $\begin{array}{l}\text { Pemahaman } \\
\text { Konsep } \\
\left(\mathrm{Y}_{1}\right)\end{array}$ & $\begin{array}{l}\text { - Memahami pengertian kelas } \\
\text { maya } \\
\text { - Memahami model } \text {-learning } \\
\text { - Menerapkan pengetahuan tentang } \\
\text { kelas maya dan jenis-jenis } \\
\text { perangkat lunak pendukung kelas } \\
\text { maya } \\
\text { - Memahami pengertian } S L N \\
\text { - Memahami pengertian } S L N / S L N S \\
\text { - Menjelaskan Edmodo sebagai } \\
\text { - } S L N \\
\text { Mempraktekkan pembuatan akun } \\
\text { - Mema } \\
\text { - Menerokami visualisasi konsep } \\
\text { - Memahami jenis praproduksi } \\
\text { - Menyajikan presentasi video }\end{array}$ & Tes \\
\hline 3. & $\begin{array}{l}\text { Prestasi } \\
\text { Belajar }\left(\mathrm{Y}_{2}\right)\end{array}$ & - Dokumentasi Nilai & $\begin{array}{c}\text { Dokumentasi } \\
\text { Nilai }\end{array}$ \\
\hline
\end{tabular}


Penelitian ini dilaksanakan di SMK Negeri 2 Trenggalek pada pertengahan semester genap tahun pelajaran 2017/2018 tepatnya pada bulan April 2018 terhadap kelas X jurusan Rekayasa Perangkat Lunak dengan menggunakan media pembelajaran SLN Edmodo pada kompetensi dasar kelas maya, sinopsis, naskah dan storyboard.

\section{B. Teknik Pengumpulan Data}

Populasi yang digunakan adalah seluruh siswa kelas $\mathrm{X}$ jurusan Rekayasa Perangkat Lunak di SMK Negeri 2 Trenggalek Tahun Pelajaran 2017/2018 yang berjumlah 107 siswa. Sampel dalam penelitian ini adalah kelas X RPL A sebagai kelas kontrol berjumlah 36 siswa dan X RPL C sebagai kelas eksperimen berjumlah 36 siswa. Sebelum instrumen angket dan soal tes diujikan kepada kelas sampel, di uji coba terlebih dahulu kepada siswa di luar populasi yang telah mempelajari materi Simulasi dan Komunikasi Digital yakni siswa kelas X RPL B yang berjumlah 35 siswa. Pengambilan sampel dengan teknik Sampling Purposive, yakni peneliti mengambil anggota sampel dengan pertimbangan tertentu. Sampel yang diambil dalam penelitian ini adalah kelas X RPL A dan X RPL C. Peneliti mengambil kelas ini karena karena jumlah sampel populasi yang digunakan sama.

Prosedur yang dilakukan meliputi tahap persiapan, pelaksanaan penelitian, dan tahap penyajian hasil penelitian. Perangkat pembelajaran pada penelitian ini terdiri dari silabus, rencana pelaksanaan pembelajaran, dan e-book. Dengan instrumen penelitian adalah angket media pembelajaran $S L N$ Edmodo, tes hasil belajar dan dokumentasi nilai siswa. Angket media pembelajaran SLN Edmodo dan tes diuji cobakan terlebih dahulu dan dilakukan analisa menggunakan software SPSS versi 23.

Analisis data angket disebarkan pada responden menggunakan skala Likert dengan pernyataan bentuk checklist yang terdiri dari lima alternatif jawaban yaitu Sangat Setuju (SS), Setuju (S), Kurang Setuju (KS), Tidak Setuju (TS) dan Sangat Tidak Setuju (STS). Angket digunakan untuk mendukung tes dalam penelitian ini. Adapun skor per item disajikan pada tabel sebagai berikut.

TABEL III

SKOR ALTERNATIF JAWABAN INSTRUMEN [Sumber: Riduwan, 2010, hal.16]

\begin{tabular}{|l|c|l|c|}
\hline \multicolumn{1}{|c|}{ Pernyataan Positif } & Skor & \multicolumn{1}{c|}{ Pernyataaan Negatif } & Skor \\
\hline Sangat Setuju (SS) & 5 & Sangat Setuju (SS) & 1 \\
\hline Setuju (S) & 4 & Setuju (S) & 2 \\
\hline Kurang Setuju (KS) & 3 & Kurang Setuju (KS) & 3 \\
\hline Tidak Setuju (TS) & 2 & Tidak Setuju (TS) & 4 \\
\hline Sangat Tidak Setuju (STS) & 1 & Sangat Tidak Setuju (STS) & 5 \\
\hline
\end{tabular}

Adapun acuan mencari interval kelas dengan rumus[3]:
TABEL IV

KRITERIA INTERPRETASI SKOR

[Sumber: Riduwan, 2010, hal.36)

\begin{tabular}{|c|l|}
\hline \multicolumn{2}{|c|}{$[$ Sumber: Riduwan, 2010, hal.36) } \\
\hline $81 \%-100 \%$ & $=$ Sangat Kuat \\
$61 \%-80 \%$ & $=$ Kuat \\
\hline $41 \%-60 \%$ & $=$ Cukup \\
\hline $21 \%-40 \%$ & $=$ Lemah \\
\hline $0 \%-20 \%$ & $=$ Sangat Lemah \\
\hline
\end{tabular}

Tes dikembangkan berdasarkan butir-butir instrumen pertanyaan dari indikator yang dibuat setelah melewati uji validitas dan uji reliabilitas. Tes yang digunakan berupa tes objektif berbentuk optional atau pilihan ganda. Materi yang digunakan adalah e-book Simulasi dan Komunikasi Digital berjumlah 15 butir soal. Untuk mendeskripsikan hasil tes soal pemahaman konsep siswa, data dapat dianalisis dengan rumus persentase sebagai berikut[4].

\section{Keterangan:}

$$
\begin{array}{ll}
P & =\text { Angka persentase hasil belajar siswa } \\
F & =\text { Frekuensi yang sedang dicari persentasenya } \\
N & =\text { Jumlah skor maksimum }
\end{array}
$$

Kemudian untuk mengetahui kategori hasil belajar siswa maka menggunakan pedoman sebagai berikut.

TABEL V

DISTRIBUSI FREKUENSI SKOR TES

[Sumber: Data SMK Negeri 2 Trenggalek]

\begin{tabular}{|c|c|l|}
\hline \multicolumn{3}{|c|}{ [Sumber: Data SMK Negeri 2 Trenggalek] } \\
\hline No. & Interval & \multicolumn{1}{|c|}{ Klasifikasi } \\
\hline 1 & $90-100$ & Sangat Baik (A) \\
\hline 2 & $81-89$ & Baik (B) \\
\hline 3 & $75-80$ & Cukup (C) \\
\hline 4 & $70-74$ & Kurang (K) \\
\hline 5 & $<70$ & Sangat Kurang (E) \\
\hline
\end{tabular}

Pada penelitian ini tes juga dilakukan uji daya pembeda dan uji tingkat kesukaran sebelum diukur melalui hasil pretest dan posttest.

Dokumentasi nilai diperoleh peneliti dari guru yang mengampu mata pelajaran Simulasi Digital. Dokumentasi nilai yang digunakan adalah hasil ulangan tengah semester (UTS) siswa Semester Genap Tahun Pelajaran 2017/2018. Setelah dinyatakan memenuhi maka dilakukan uji normalitas, uji linieritas, uji homogenitas dan uji t-test.

Kriteria pengambilan keputusan dari uji tersebut ditentukan melalui taraf signifikansi sebagai berikut. Jika Jika signifikansi > 0,05 maka $\mathrm{H}_{0}$ diterima (varian sama). Jika signifikansi $<0,05$ maka $\mathrm{H}_{\mathrm{a}}$ ditolak (varian berbeda). Data yang sudah diperoleh dirubah dalam bentuk angka sebelum kemudian ditarik kesimpulan dan disesuaikan dengan persentase penilaian respon siswa.

\footnotetext{
Keterangan:

$P \quad=$ Panjang Kelas Interval

$R \quad=$ Data Tertinggi - Data Terendah

$K \quad=$ Jumlah Kelas
} 


\section{HASIL DAN PEMBAHASAN}

Data penggunaan SLN Edmodo dalam pembelajaran siswa kelas X RPL B semester genap SMK Negeri 2 Trenggalek tahun pelajaran 2017/2018 diperoleh dari pengolahan angket yang terkumpul. Adapun data diperoleh dari kelas eksperimen setelah siswa mendapatkan perlakuan pada mata pelajaran Simulasi dan Komunikasi Digital. Data telah diolah dalam bentuk grafik sebagai berikut.

Grafik I

Pengaruh SLN Edmodo pada siswa kelas X RPL C di SMK Negeri 2 Trenggalek

[Sumber: Lampiran 8]

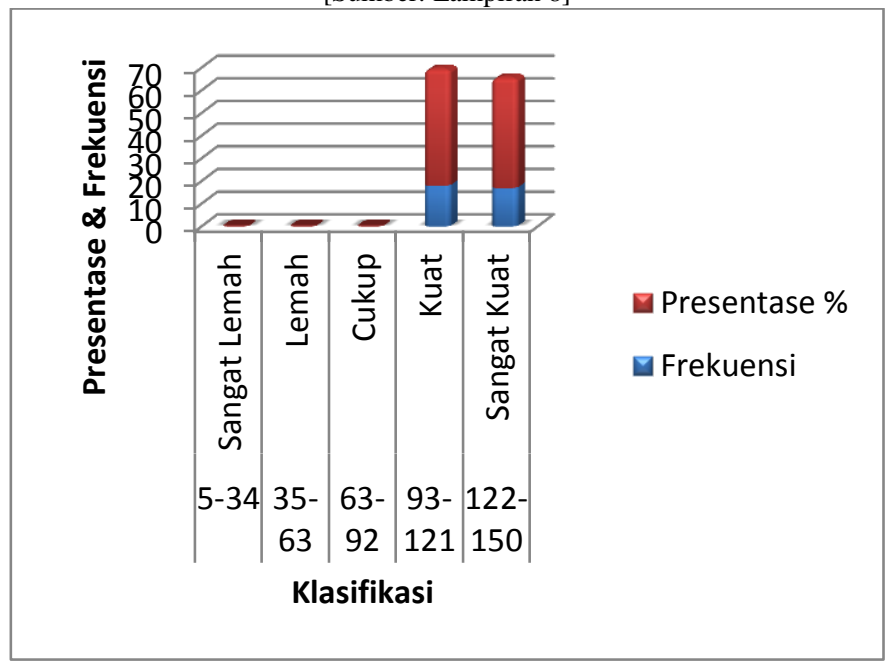

Berdasarkan grafik diatas, menunjukkan bahwa uji validasi dari 35 siswa kelas X RPL B di SMK Negeri 2 Trenggalek menunjukkan kegiatan SLN Edmodo yang baik, hal ini terbukti ada 17 siswa (49\%) sangat kuat, 18 siswa (51\%) kuat dan 0 siswa (0\%) cukup. Jadi dapat disimpulkan bahwa SLN Edmodo itu pada siswa kelas X RPL C di SMK Negeri 2 Trenggalek Tahun Pelajaran 2017/2018 dalam kategori kuat dan dapat digunakan pada kegiatan pembelajaran. Berikut adalah gambaran tampilan media SLN Edmodo.

Gambar 1

Tampilan Login User Interface SLN Edmodo [Sumber: Lampiran 5]

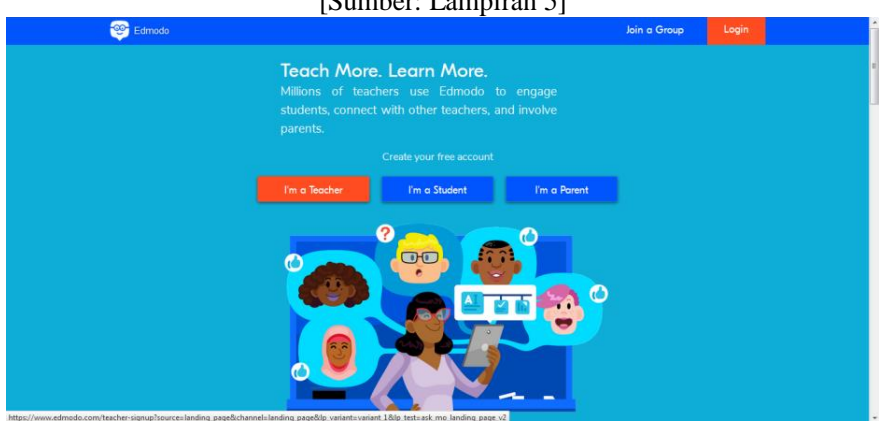

Gambar 2

Tampilan Beranda SLN Edmodo

[Sumber: Lampiran 5]

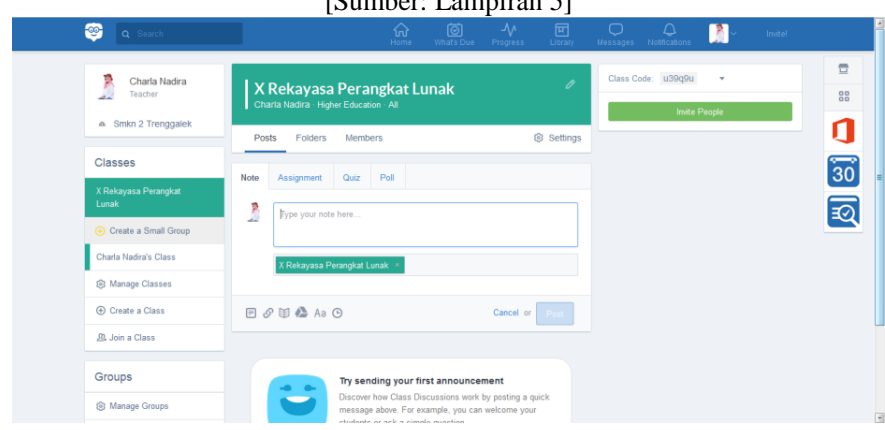

Gambar 3

Tampilan Pengerjaan Kuis Tes Pemahaman Konsep dengan Edmodo [Sumber: Lampiran 5]

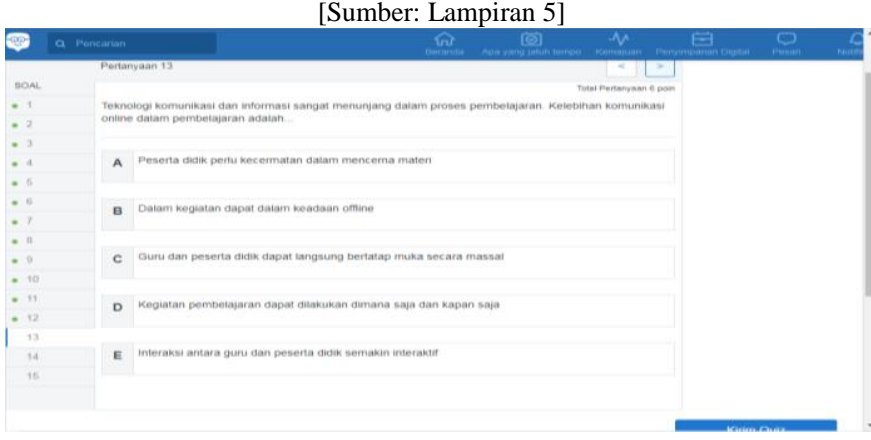

Gambar 4

Tampilan Progress Hasil Pengerjaan Kuis Siswa dalam Bentuk Diagram [Sumber: Lampiran 5]

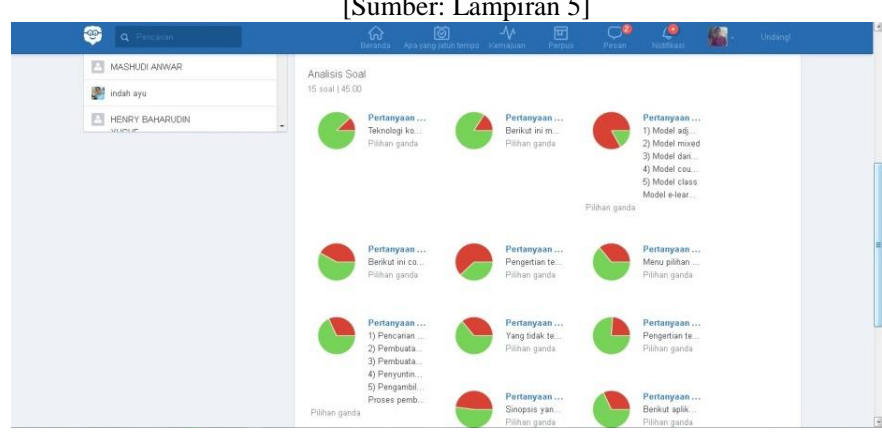

Gambar 5

Tampilan Nilai Kuis Siswa

[Sumber: Lampiran 5]

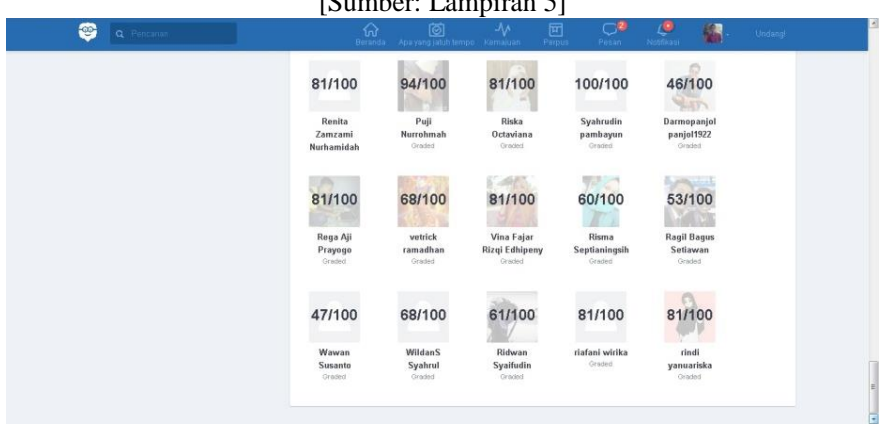

Hasil uji validitas angket SLN Edmodo, menggunakan rtabel dengan taraf signifikasi 5\% dengan jumlah responden sebanyak 35 orang maka $\mathrm{df}=30$. 
Dari uji coba angket SLN Edmodo tersebut ternyata koefisien korelasi semua butir dengan skor total diatas 0,361 , sehingga semua butir instrumen SLN Edmodo dinyatakan valid. Butir yang mempunyai validitas tertinggi adalah butir 22, dengan koefisien korelasi 0,763 dan paling rendah adalah butir nomor 24 dengan koefisien korelasi 0,369. Adapun uji reliabilitas angket SLN Edmodo diketahui bahwa nilai $\alpha$ sebesar 0,744. Adapun distribusi nilai ${ }_{\mathrm{r}}$ tabel signifikansi 5\% diperoleh nilai ${ }_{\mathrm{r}}$ tabel sebesar 0,361. Sehingga dapat disimpulkan $\alpha=0,744>0,361$ artinya item-item angket $S L N$ Edmodo reliabel sebagai alat pengumpul data dalam penelitian.

Pada uji coba instrumen soal tes pemahaman konsep, menggunakan rtabel dengan taraf signifikasi 5\% dengan jumlah responden sebanyak 35 orang maka $d f=30$. Sehingga didapatkan nilai rtabel dua sisi sebanyak 0,361. Dari hasil tabel ternyata koefisien korelasi butir soal tes menunjukkan sebanyak 15 butir soal dengan skor total dibawah 0,361 dan 15 butir soal dengan skor total diatas diatas 0,361 dinyatakan valid. Sehingga pengambilan keputusan jika ${ }_{\mathrm{r}}$ hitung $<{ }_{\mathrm{r}}$ tabel maka diambil butir pertanyaan yang valid kemudian diujikan kembali untuk mengetahui tingkat validitas instrumen tersebut.

Adapun uji reliabilitas tes pemahaman konsep Adapun distribusi nilai rtabel signifikansi 5\% diperoleh nilai rtabel sebesar 0,514 Sehingga dapat disimpulkan $\alpha=0,870>0,514$ artinya item-item soal tes pemahaman konsep reliabel sebagai alat pengumpul data dalam penelitian.

Hasil uji normalitas data menggunakan uji Liliefors ditemukan signifikansi kelompok kontrol posttest sebesar $\alpha=$ $0,016>0,05$ dan signifikansi kelompok eksperimen posttest sebesar $\alpha=0,020>0,05$. Karena nilai sig. (2-tailed) menunjukkan $\alpha>0,05$, maka distribusi data variabel pemahaman konsep $\left(\mathrm{Y}_{1}\right)$ tersebut normal.

Uji tingkat kesukaran dilakukan untuk mengetahui tingkat kesukaran soal yang digunakan untuk instrumen pemahaman konsep mana yang termasuk sangat mudah, sedang dan sangat sukar. Setelah dihitung ternyata dari 15 butir instrumen tes terdapat 1 soal kategori sangat sukar dan 14 soal dengan kategori sedang. Sehingga berdasarkan tabel tersebut rata-rata butir instrumen berada dalam kategori sedang.

Uji daya pembeda digunakan untuk mengetahui butir instrumen tes terdapat dalam kategori sangat buruk, buruk, kurang baik, baik dan sangat baik. diketahui hasil uji daya beda dari 15 instrumen soal, terdapat 6 soal kategori sangat baik dan 7 soal kategori baik. Sehingga rata-rata uji daya pembeda soal berada dalam kategori baik.

Uji linearitas data ditemukan signifikansi kelompok kontrol posttest sebesar $\alpha=0,322>0,05$ dan signifikansi kelompok eksperimen posttest $\alpha=0,085>0,05$. Karena uji linearitas masing-masing nilai sig. (2-tailed) menunjukkan $\alpha>0,05$, maka hubungan antara kedua variabel kelompok kontrol posttest dan kelompok eksperimen posttest tersebut dinyatakan linear.

Uji homogenitas yang dilakukan ada 2 yaitu uji homogenitas menguji kelompok kontrol pretest dan kelompok eksperimen pretest untuk mengetahui kesetaraan kelas yang akan digunakan penelitian, dan uji homogenitas kelompok kontrol posttest dan kelompok eksperimen posttest untuk digunakan pada pengujian hipotesis. Uji homogenitas menggunakan rumus One Way ANOVA. ditemukan bahwa keempat kelompok tersebut memiliki varian yang homogen. Dengan signifikansi kelompok kontrol pretest sebesar $\alpha=$ $0,258>0,05$ dan kelompok eksperimen pretest sebesar $\alpha=$ $0,581>0,05$, maka hubungan antara kedua kelompok tersebut dinyatakan homogen. Selanjutnya uji signifikansi kelompok kontrol posttest sebesar $\alpha=0,354>0,05$ dan kelompok eksperimen posttest sebesar $\alpha=0,089>0,05$, maka hubungan kedua kelompok tersebut dinyatakan homogen.

Hasil uji T-Test menunjukkan signifikansi variabel pemahaman konsep $\left(\mathrm{Y}_{1}\right)$ sebesar $\alpha=0,796>0,05$ dan variabel prestasi belajar $\left(\mathrm{Y}_{2}\right)$ sebesar $\alpha=0,563>0,05$ maka $\mathrm{H}_{0}$ diterima. Sehingga dapat disimpulkan bahwa antara variabel pemahaman konsep dan prestasi belajar memiliki varian yang sama. Hasil pengujian hipotesis menunjukkan bahwa penggunaan media Social Learning Network berbasis Edmodo berpengaruh signifikan terhadap pemahaman konsep dan prestasi belajar siswa.

\section{A. Pengaruh SLN Edmodo terhadap pemahaman konsep siswa pada mata pelajaran simulasi digital di SMK Negeri 2 Trenggalek.}

Pada awal penelitian diketahui bahwa hasil pretest pada kelas X RPL A (kelompok kontrol) masuk ke dalam kategori sangat kurang sebesar 94,4\% dan hasil pretest kelas X RPL C (kelompok eksperimen) juga dalam kategori sangat kurang sebesar 86,1\%. Kedua kelas tersebut kemudian diuji homogenitasnya dan didapatkan hasil uji homogenitas kelompok kontrol pretest memiliki signifikansi sebesar $\alpha=$ $0,258>0,05$, dan kelompok eksperimen pretest sebesar $\alpha=$ $0,581>0,05$ sehingga dapat dikatakan kedua kelompok memiliki kondisi awal yang homogen. Setelah diuji kedua kelompok dikenai perlakuan yang berbeda, kelompok kontrol melangsungkan pembelajaran tanpa menggunakan SLN Edmodo dan kelompok eksperimen melangsungkan pembelajaran berbasis SLN Edmodo. Dari kedua kelompok diujikan kembali menggunakan tes, hasil posttest kedua kelompok tersebut ternyata kelompok yang menggunakan SLN Edmodo memiliki perubahan yang signifikan terhadap pemahaman konsep siswa yakni dalam kategori baik sebesar $38,9 \%$. Siswa yang menggunakan SLN Edmodo meningkat terhadap pemahaman konsep materi simulasi digital karena kemudahan akses materi dan waktu yang fleksibel. Adanya respon timbal balik saat menggunakan SLN Edmodo dari guru ke siswa juga berdampak positif, contohnya siswa senang belajar menggunakan SLN Edmodo sehingga berdampak pada pemahaman konsep siswa yang meningkat.

Hal ini sesuai dengan penelitian yang dilakukan oleh Rismayanti (2016) seperti dikutip Retnoningsih (2017) dengan Edmodo akan lebih mudah memonitor interaksi siswa dalam Edmodo Learning Environment. Menyediakan lingkungan dimana siswa menjadi lebih mandiri, tanpa melupakan standar pengukuran keberhasilan siswa[5].

Adapun hasil pengujian hipotesis dengan analisis uji T-Test menunjukkan bahwa signifikansi pemahaman konsep $\left(\mathrm{Y}_{1}\right)$ sebesar $\alpha=0,796>0,05$. Dengan demikian maka hipotesis nol diterima, kesimpulannya yaitu media SLN Edmodo 
berpengaruh terhadap pemahaman konsep di SMK Negeri 2 Trenggalek. Dari hasil pembahasan diatas menunjukkan bahwa ada pengaruh yang signifikan antara SLN Edmodo terhadap pemahaman konsep siswa pada kelas $\mathrm{X}$ jurusan Rekayasa Perangkat Lunak di SMK Negeri 2 Trenggalek.

\section{B. Pengaruh SLN Edmodo terhadap prestasi belajar siswa pada mata pelajaran Simulasi Digital di SMK Negeri 2 Trenggalek}

Dari hasil pembahasan diatas, diketahui signifikansi prestasi belajar $\left(\mathrm{Y}_{2}\right)$ sebesar $\alpha=0,563>0,05$. Karena nilai signifikansi > 0,05 maka $\mathrm{H}_{0}$ diterima. Jadi dapat disimpulkan bahwa variabel prestasi belajar memiliki varian yang sama. Berdasarkan hal tersebut dapat disimpulkan bahwa media Social Learning Network (SLN) berpengaruh terhadap prestasi belajar siswa. Sebagaimana hasil penelitian yang dilakukan oleh Nasrullah, dkk (2017) juga menunjukkan bahwa: 1) pembelajaran matematika ekonomi yang menggunakan Edmodo (eksperimen) lebih baik dibandingkan dengan pembelajaran tanpa menggunakan Edmodo (konvensional) terhadap komunikasi matematis dan 2) mahasiswa yang belajar dengan menggunakan Edmodo bersikap positif terhadap pembelajaran matematika ekonomi[6].

Dari analisis uji hipotesis diketahui bahwa signifikansi pemahaman konsep $\left(\mathrm{Y}_{1}\right)$ sebesar $\alpha=0,796>$ prestasi belajar $\left(\mathrm{Y}_{2}\right)$ sebesar $\alpha=0,563$. Tes yang dilakukan oleh peneliti memiliki signifikansi yang lebih besar dibandingkan dokumentasi nilai UTS pada variabel prestasi belajar. Uji hipotesis tersebut membuktikan bahwa penggunaan media SLN Edmodo berpengaruh signifikan terhadap variabel pemahaman konsep dan variabel prestasi belajar siswa, oleh sebab itu perlu adanya penerapan SLN Edmodo pada mata pelajaran Simulasi Digital sebagai penunjang untuk meningkatkan pemahaman konsep dan prestasi belajar siswa. Selain itu, penelitian yang dilakukan oleh Al-Kathiri (2015) menunjukkan penggunaan Edmodo memiliki banyak tantangan dan potensi yang bagus dalam pembelajaran[7].

Hal yang sama juga dikemukakan oleh Gomez, Magrenan, \& Orcos (2015) bahwa penggunaan Edmodo dapat membantu mengembangkan kompetensi: kemampuan manggunakan media, kolaborasi virtual dan pengelolaan kognitif yang sejalan dengan hasil penelitian. Selain itu, nilai lebih dari Edmodo adalah orang tua siswa dapat memantau perkembangan kegiatan belajar putra-putri mereka[8]. Dengan pembelajaran media Social Learning Network (SLN) membantu siswa untuk meningkatkan pemahaman konsep dan prestasi belajar siswa.

\section{PENUTUP}

\section{A. Kesimpulan}

Berdasarkan penelitian yang telah dilakukan bahwa adanya pengaruh SLN Edmodo terhadap pemahaman konsep siswa kelas X mata pelajaran Simulasi Digital di SMK Negeri 2 Trenggalek. Pengujian dibuktikan dengan hipotesis menggunakan analisis uji T-Test bahwa signifikansi pemahaman konsep $\left(\mathrm{Y}_{1}\right)$ sebesar $\alpha=0,796>0,05$. Sehingga media SLN Edmodo berpengaruh terhadap pemahaman konsep di SMK Negeri 2 Trenggalek.
Berdasarkan hasil analisis yang telah dilakukan media SLN Edmodo memiliki pengaruh terhadap prestasi belajar siswa kelas X mata pelajaran Simulasi Digital di SMK Negeri 2 Trenggalek. Hasil analisis yang telah dilakukan menggunakan uji T-Test bahwa signifikansi prestasi belajar $\left(\mathrm{Y}_{2}\right)$ sebesar $\alpha=$ $0,563>0,05$. Karena nilai signifikansi > 0,05 maka $\mathrm{H}_{0}$ diterima. Jadi dapat disimpulkan bahwa variabel prestasi belajar memiliki varian yang sama. Berdasarkan hal tersebut dapat disimpulkan bahwa media Social Learning Network $(S L N)$ berpengaruh terhadap prestasi belajar siswa.

\section{B. Saran}

1) Bagi guru, disarankan untuk menggunakan media pembelajaran Edmodo didukung dengan adanya kelas virtual Edmodo sebagai pendukung pembelajaran di sekolah bahwa media ini menjadi solusi keterbatasan waktu pada saat tatap muka di kelas.

2) Bagi sekolah, sarana dan prasarana yang sudah memadai dan baik dapat menunjang pembelajaran modern berbasis virtual diharapkan mampu meningkatkan produktivitas akademik maupun non-akademik.

3) Bagi peneliti selanjutnya, yang akan menggunakan media pembelajaran disarankan untuk meneliti penggunaan bantuan media sosial bertemakan pendidikan lainnya misalnya ThinkQuest, Hoodemia, Moodle dan media sosial yang lainnya pada materi yang berbeda.

\section{UCAPAN TERIMA KASIH}

Terima kasih disampaikan kepada Bapak Ari Mardian, S.Pd., Kepala Sekolah SMK Negeri 2 Trenggalek (Drs. Asbandi) dan STKIP PGRI Tulungagung.

\section{REFERENSI}

[1] Kementerian Pendidikan dan Kebudayaan Direktorat Jenderal Guru dan Tenaga Kependidikan. (2016). Petunjuk Teknis Program Peningkatan Kompetensi Guru Pembelajar. Diperoleh dari https://www.vedcmalang.com

[2] Kementerian Pendidikan dan Kebudayaan Republik Indonesia. (2017). Bahan Ajar Simulasi dan Komunikasi Digital. Diperoleh dari SMKN 2 Trenggalek.

[3] Riduwan. (2010). Rumus dan Data dalam Analisis Statistika. Bandung: Alfabeta.

[4] Bungin, Burhan. (2011). Metodologi Penelitian Kuantitatif. Jakarta: Kencana.

[5] Retnoningsih, Endang. (2017). Perbandingan Learning Management System Edmodo dan Moodle dalam Pembelajaran Online. Information System for Educators and Professionals, Vol. 1 (2), 221-230. Diperoleh dari ejournal-binainsani.ac.id

[6] Nasrullah, A. dkk (2017). Efektivitas Penggunaan Media Edmodo pada Pembelajaran Matematika Ekonomi terhadap Komunikasi Matematis. Pasundan Journal of Research in Mathematics Learning and Education, Vol. 2 (1), 1-10. Diperoleh dari journal.unpas.ac.id

[7] Al-Kathiri, F. (2015). Beyond the Classroom Walls: Edmodo in Saudi Secondary School EFL Instruction, Attitudes and Challenges. Journal Canadian Center of Science and Education, Vol. 8 (1), 189-204. Diperoleh dari https://files.eric.ed.gov

[8] Gomez, A., Magrenan, Á. A., \& Orcos, L. (2015). UX of Social Network Edmodo in Undergraduate Engineering Students. International Journal of Artificial Intelligence and Interactive Multimedia, Vol. 3 (4), 31-36. Diperoleh dari http://doi.org 